\title{
Sociopoetics in the Work of Shakespeare
}

\author{
Thomas Bechtold
}

This article develops an immanent critique following the dialogism of Mikhail Bakhtin in his literary criticism of socio-poetics. ${ }^{1}$ Socio-poetics in the reception and composition of Shakespeare's works reflect the first intimations of social and political transformation to a modern nationalized society from a premodern feudal society. This article explores Shakespeare's use of metaphor through his dramatizations and characterizations at the dawn of modernity and the decline of feudalism: identifying contradictions and tensions that intimate this transformation in English society and language, and providing an approach to this globalizing language that partakes in simultaneous modes of confabulation and possible de-commodification of that language through an understanding founded in a socio-poetics. Shakespeare's unique historical position in delimiting later formations of the English language, his composition of modes of reference and literacy, also prepares a potential critique of the contemporary use of figurative language in the present socio-political moment.

\section{Introduction}

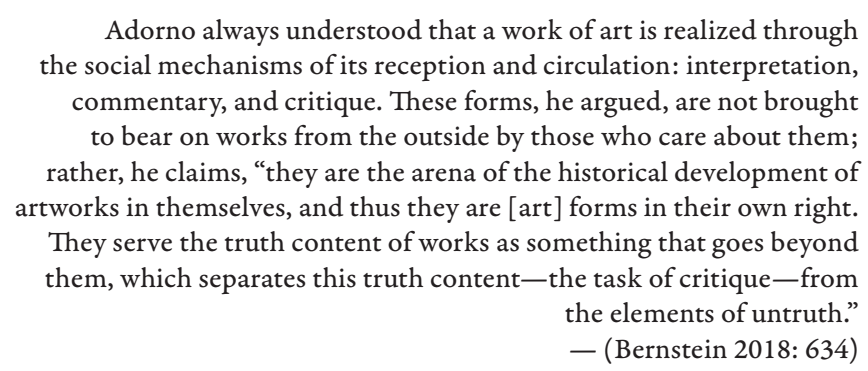

The process of realizing the work of artists is not simply protective and curatorial. Critique, with which readers of Theodeore W. Adorno are familiar, but also interpretation and commentary are vital in the socioanalysis of literature. Figurative language in its overstating and understating, with its surpluses and deficits, knowingly performs a mimesis of inimitable phenomena. When those phenomena are events, moments, contingencies, dependencies, relations and processes, never fixed and concrete in their givenness to our senses, we are rightly critical of that misplaced concreteness that we experience in their institutions, status, and reproduction. ${ }^{2}$

Unlike the hypothetical cases used in analysis of these events and moments, figures of speech are the un-like and imperfect mimesis that abstract these moments from context and gives them over to articulation and intelligibility. The distinguishing mark of using literature or art to inform social science appears first as interpretative of the evidence, not simply explanatory of it (Jameson 1981). With this form of evidence, interpretation is also an adoption of distinguishing criteria allowing for critique; and to do so knowingly, and that means reflexively, allowing for commentary. ${ }^{3}$

We cannot rely upon brute facts or the hypothetical cases used for abstract conceptualization without carrying out an imprecise reading of the texts that we encounter. By relying on the putatively literal and denotative we are not engaged in precision and rigor. Instead, we are engaged in a distortion that short-circuits understanding as to the yield 
of an interpretative approach; we are instead engaged in the alienation of reason as functionaries of instrumental rationality.

All the following texts have predecessors and are effectively retelling of earlier stories. ${ }^{4}$ While I will limit myself to specific texts and specific discourses, a next step would be to do more than give the putative historical confines of the dramas their predecessors and their successive revisions, abridgments, and adaptations. For example, I will not discuss the supposed predecessor stories in "Naufragium” or Colloquia Familiaria, or Peter Martyr's De orbo novo, William Strachey's A True Reportory of the Wracke and Redemption of Sir Thomas Gates, Knight in relation to The Tempest. Nor will I pursue the better-understood emplotment of The Winter's Tale from Robert Greene's pastoral romance $\underline{\text { Pandosto. }}$

Most important is the metaphor that can say at once and directly in the single-voiced ${ }^{5}$ drama what cannot be said otherwise. This is where the affectation, subjectivity, speech, and subjugation of the mute classes can be discovered most easily. The servants cannot speak, are forcibly denied in some cases, but their actions can speak and no doubt their performance spoke to the audience. Just as then, we need to listen to those voices.

The metaphor is of particular value in the single-voicedness of the medieval dramatist that Shakespeare follows. By using two disparate tropes and condensing them, we are forced into the unpacking of the metaphor in reading as a way of awakening our senses to the differences between even the most like and comparable of things. This is the 'magic' of literature, a fusion of difference into a single intelligible constellation; relational and knowable connotatively. It is evident then that such language can be easily construed as private when the metaphor requires learning or cultural familiarity. On the contrary, some metaphors are meant to reach into the plainly evident and readily available, teasing our 'common sense.'

A socio-analysis that takes literature for its evidence is faced with the surplus of meaning that figurative language proliferates. This surplus can be evaded by a kind of 'short-circuit effect' that Pierre Bourdieu notes in the too quick correspondence of social issues in a fictional text to ongoing class struggle (Bourdieu 1993). I will attempt to avoid this pitfall by diving headlong into another; the prolix work of Shakespeare allows that the ideologemes of his texts do indeed always say more than we recognize and generate ambiguity at their horizon.

\section{The Ideologeme}

We can compare the ideologeme to the mytheme of Lévi-Strauss related by Paul Ricouer: “...a mytheme is not one of the sentences of the myth but an oppositive value that is shared by several particular sentences, constituting, in the language of Lévi-Strauss, a 'bundle of relations'.” (Ricouer 1991: 115). We are forced to speak of ideologemes in relation to one another, in a structural arrangement, disposition, or assemblage, that is, like the text, and often in metaphor.

For Bakhtin/Medvedev, the ideologeme is an ethic, psychology, or philosophy—a value system—only analytically separable from the text in which it appears. No plot (nor emplotment), no story, no theme, no motif is possible or concrete until it has been refracted through the 'prism of the ideological environment." (Bakhtin and Medvedev 1978:13-15) Here again, we can turn to Ricouer where he notes that we may speak of a literary world as 'the Greek world,' or the 'Byzantine world,' meaning the imaginary that comes from the texts that make up this literature. When we speak of an ideologeme we are not just speaking of these literary values as they reference these 'worlds,' we are speaking of sociopoietically formed values that are oppositional, again, Bakhtin/Medvedev: "This formula is composed of ideological conflicts, material forces which have been ideologically refracted. Good, evil, truth, crime, duty, death, love, victory, etc.—all are ideological values without which there can be no plot or motif." (Bakhtin and Medvedev 1978: 17)

It is important to recall Julia Kristeva's insight into the ideologeme here: "The ideologeme is the intersection of a given textual arrangement (a semiotic practice) with the utterances (sequences) that it either assimilates into its own space or to which it refers in the space of exterior texts (semiotic practices)" (Kristeva 1980: 36). ${ }^{8}$

Bakhtin/Medvedev points out that the characters, personae that we readily identify and are familiar with, are an ideological refraction: “... an inseparable element of the unified ideological horizon of the social group..." (Bakhtin and Medvedev 1978) and that they are particular to an era; we cannot identify the hero of a 19th-century romance with the hero of a classical Greek tragedy. The ideologeme also has another function, what Bakhtin/Medvedev refers to as its 'poetic function' in providing closure to the artistic work. This is the single-voiced authorial monologue that 
closes itself to the multi-voiced substrate - the dialogue that this poetics is drawn from and this monologue obviates. This is a social statement; a tacit political statement of the authority of an author, and the mimesis of authority, as a reflection and refraction of a division of intellectual labor privileging the author as the final authority and origin of the work.

\section{Prospero}

The first ideologeme we will encounter here is that of the author as authority; Shakespeare's voice in The Tempest as Prospero- - patriarch, duke, and magician — the authors' words form the texts of The 'Tempest. ${ }^{9}$ 'The story of the domination of nature is not merely the magical rule of an island; it is the domination of natures and desires through unchristian magic.

The protagonist, Prospero, is only possible from the horizon of his grotesques; Ariel, Caliban, silent Sycorax, and even the demonic Setebos, but also the clowns and characters that people Prospero's closed world.

First, Ariel:

ARIEL

Pardon, master;

I will be correspondent to command

And do my spiriting gently.

PROSPERO

Do so, and after two days

I will discharge thee.

ARIEL

That's my noble master!

What shall I do? say what; what shall I do?

PROSPERO

Go make thyself like a nymph o' the sea: be subject

To no sight but thine and mine, invisible

To every eyeball else. Go take this shape

And hither come in't: go, hence with diligence!

Ariel is the good servant, but alas poor Caliban whom Prospero introduces as: "A freckled whelp hag-born--not honour'd with A human shape.”:

\section{PROSPERO}

Thou most lying slave,

Whom stripes may move, not kindness! I have used thee, Filth as thou art, with human care, and lodged thee

In mine own cell, till thou didst seek to violate

The honour of my child.

\section{CALIBAN}

O ho, O ho! would't had been done!

Thou didst prevent me; I had peopled else

This isle with Calibans.

\section{PROSPERO}

Abhorred slave,

Which any print of goodness wilt not take,

Being capable of all ill! I pitied thee,

Took pains to make thee speak, taught thee each hour

One thing or other: when thou didst not, savage,

Know thine own meaning, but wouldst gabble like

A thing most brutish, I endow'd thy purposes

With words that made them known. But thy vile race,

Though thou didst learn, had that in't which

good natures

Could not abide to be with; therefore wast thou

Deservedly confined into this rock,

Who hadst deserved more than a prison. 


\section{CALIBAN}

You taught me language; and my profit on't

Is, I know how to curse. The red plague rid you

For learning me your language!

What Bakhtin recognizes as heteroglossia, multi-voicedness, and polyphony, Kristeva develops for its system and form. ${ }^{10}$ What are these systems? Plainly put, the value systems of a medieval society; the values of divine providence, of monarchy, of aristocratic excellence, and, of the grotesque subject in the over-statements of billingsgate, abuse, bodily comedy; of folk religion, magic and superstition; of the absurd, utterly fanciful, and the monstrous.

For Prospero to disabuse Caliban with vehemence in the preceding passage is to witness the play of Shakespeare's appeal to aristocratic affect and at the same time to avow a comedy of threats and abuse, and to tempt that comedy with Caliban's sexual interests in the chaste Miranda. This exchange also reveals attitudes towards magic, followed by Prospero's threats to curse Caliban. Magic is the property of the educated in renaissance Europe, the most notorious figure in England at the time of Shakespeare being John Dee, ${ }^{11}$ and whether it is Prospero's teaching Caliban to speak or to rack him with cramps, it is a blurred line in the medieval imagination.

The art of Prospero is occasionally vengeful sorcery:

\section{PROSPERO}

Hag-seed, hence!

Fetch us in fuel; and be quick, thou'rt best,

To answer other business. Shrug'st thou, malice?

If thou neglect'st or dost unwillingly

What I command, I'll rack thee with old cramps,

Fill all thy bones with aches, make thee roar

That beasts shall tremble at thy din.

\section{CALIBAN}

No, pray thee.

Aside

I must obey: his art is of such power,

It would control my dam's god, Setebos,

and make a vassal of him.

The magic of Prospero is the inverse of a human's relation to nature. It is possible to understand the overwhelming effects of nature in a drought or a plague and it is possible to understand that illness and health are not matters of individual art, the influenza of the ancient world is after all 'influence from the stars.' What is this magic then? It is the wish and the reversal of these conditions. To command the elements, to dominate nature, to reverse nature and culture, is the anthropomorphic art of Prospero.

Adorno and Horkheimer on this point:

"Enlightenment is always the critique of myth; what defines a content as mythic from the perspective of enlightenment is that it originates from an illegitimate anthropomorphism, the projection on to nature of what is merely human. In the first instance, identifying anthropomorphic projections was easy: gods, demons, spirits, in short all supernatural phenomena." (Bernstein 2000: 282)

The cultural vehicle of which, the spell, is of course spoken as an exhortation and in verse:

\section{EPILOGUE}

\section{SPOKEN BY PROSPERO}

Now my charms are all o'erthrown,

And what strength I have's mine own,

Which is most faint: now, 'tis true,

I must be here confined by you,

Or sent to Naples. Let me not,

Since I have my dukedom got

And pardon'd the deceiver, dwell

In this bare island by your spell;

But release me from my bands

With the help of your good hands:

Gentle breath of yours my sails

Must fill, or else my project fails, 
Which was to please. Now I want

Spirits to enforce, art to enchant,

And my ending is despair,

Unless I be relieved by prayer,

Which pierces so that it assaults

Mercy itself and frees all faults.

As you from crimes would pardon'd be,

Let your indulgence set me free.

For Bakhtin, the poetics of Shakespeare, although they contain the dialogical elements of sociopoiesis, are deficient in the self-reflexive and fully ideological sense that he cites in the poetics of Dostoevsky:

\begin{abstract}
"But to speak of a fully formed and deliberate polyphonic quality in Shakespeare's dramas is in our opinion simply impossible, and for the following reasons. First, drama is by its very nature alien to genuine polyphony; drama may be multi-leveled, but it cannot contain multiple worlds; it permits only one, and not several, systems of measurement. Secondly, if one can speak at all of a plurality of fully valid voices in Shakespeare, then it would only apply to the entire body of his work and not to individual plays. In essence each play contains only one fully valid voice, the voice of the hero, while polyphony presumes a plurality of fully valid voices within the limits of a single work-for only then may polyphonic principles be applied to the construction of the whole. Thirdly, the voices in Shakespeare are not points of view on the world to the degree they are in Dostoevsky; Shakespearean characters are not ideologists in the full sense of the word." (Bakhtin 1984: 34)
\end{abstract}

The author function, to borrow Foucault's phrase, is simply not fully developed in Shakespeare's poetics in a literary (cultural) way because the Bard's poetics have not shed the ideologeme of medieval dramatization. The author still bears something of the authority of the medieval symbol of authority in the Great Chain of Being, and is still a dominant ideologeme in the early modern era yet to be displaced. However, this is also to say that a sociopoiesis is still embryonic at this time in that the multi-voicedness of English literary imagination has yet to emerge in writing.

It is possible for Prospero to engage in the dubious practice of unchristian magic just as it is possible for Caliban to momentarily enjoy a scheme against his master and the will of providence. But Caliban can no more overthrow the art of Prospero than Prospero can deny the will of providence as his sole guide-nor the audience in a mimesis where they cannot deny their adoration of this magi and his mythification by them.

The magic of Prospero is the inheritance of the art of Sycorax and Setebos under divine providence. We can see this as the medieval consciousness in its nostalgia for social order under the great chain of being. And, we can see how this is allegorical in obviating the rise of modern science and technology $y^{12}$ in an attempt to master nature and sway it to the flux of culture.

By Horkheimer and Adorno's account, the drama reified as an allegory of medieval nostalgia is a 'schema': "In "Schema," Horkheimer and Adorno see the identificatory spell of the mass-cultural hieroglyph linked to the return of mimesis, as I suggested earlier, coupled with the resurfacing of archaic writing. "Mimesis," they propose, "explains the mysteriously empty ecstasy of the fans of mass culture." If this is clearly a perverted form of mimesis, it still feeds on its utopian opposite, the possibility of reconciliation. What "drives human beings into the movie theaters," Adorno and Horkheimer observe, as it were, in the same breath, may be "the deeply buried hope" that one day the hieroglyphic "spell may be broken." (Hansen 1992: 52)

However, the author has revealed his hand in the epilogue as many critics have noted. ${ }^{13}$ Shakespeare engages in a double-voiced ${ }^{14}$ reflexion on authorship through the poeticized narcissisms of Prospero, a point to be followed with Richard II. It is an effect that demonstrates an interiority from which a voice is supposed to originate and denied to foils and grotesques in their baseness and lack of reflexion.

\title{
Richard II
}

In Richard II we encounter a more dangerous and de-stabilizing language than the momentary allusion and crack in the fourth wall of Elizabethan drama that threatens to reveal the arbitrary and figurative in the early modern socio-political imaginary. In this history, we encounter the character of Richard as an inverted tragedy, the crime of a despot that threatens to reveal despotism, but also the narcissism of dramatization as signs of the private and interior. Here again, the ideologeme of the authority is challenged, more seriously. ${ }^{15}$

Richard II is true to Bakhtin's sense of the poetic as a closed and centripetal structure in drama; heroizing 
and tragic in that the center cannot hold. This anticipation of modernity is met within the stratagems of the monarch, Richard, and creative of the ideologeme of the tragic figure of the King unraveled as Terry Eagleton notes: "Something comes out of nothing, as Richard wrests his most elaborate fiction from the process of being dismantled." (Eagleton 1986: 12). That nothing, the estranged sign, mutable in Richard's narcissisms is the ironic seed of his destruction.

In The Tempest, the reversal of nature and culture resulted in an ideologeme that was not merely evidence of class-struggle, it is the struggle of nature against the (societal) impositions of Prospero as the successor of Sycorax and Setebos, the master of the grotesqueries of Caliban and Ariel-the less-than-human servants of Prospero-but we are fooled should we fail to see that everyone on the island is the servant of Prospero as the inheritor of the final word, in the magic wrested from Setebos in the name of a divine will. And, in a final seduction of art-this myth - the audience is given the comic closure that continues the important ideological task of suspending disbelief.

Here, the reversal is manifest in this as a tragedy, a tragedy not for Richard, but in the anglicized consciousness to the narcissisms of a king. Again, differently, culture and nature are reversed, such that a social nature is colonized by the alienated letter, and the poetics of Richard in his monomania. The symptom, of course, is the anglicized subject for whom this is a tragedy of betrayal and the ambiguity of feeling for a fallen monarch. Lest we are too tempted to euhemerization, recollect this exchange:

\author{
JOHN OF GAUNT \\ Now He that made me knows I see thee ill; \\ Ill in myself to see, and in thee seeing ill. \\ Thy death-bed is no lesser than thy land \\ Wherein thou liest in reputation sick; \\ And thou, too careless patient as thou art, \\ Commit'st thy anointed body to the cure \\ Of those physicians that first wounded thee: \\ A thousand flatterers sit within thy crown, \\ Whose compass is no bigger than thy head; \\ And yet, incaged in so small a verge, \\ The waste is no whit lesser than thy land. \\ $\mathrm{O}$, had thy grandsire with a prophet's eye \\ Seen how his son's son should destroy his sons, \\ From forth thy reach he would have laid thy shame, \\ Deposing thee before thou wert possess'd, \\ Which art possess'd now to depose thyself. \\ Why, cousin, wert thou regent of the world, \\ It were a shame to let this land by lease; \\ But for thy world enjoying but this land, \\ Is it not more than shame to shame it so? \\ Landlord of England art thou now, not king: \\ Thy state of law is bondslave to the law; And thou--

\section{KING RICHARD II} \\ A lunatic lean-witted fool, \\ Presuming on an ague's privilege, \\ Darest with thy frozen admonition \\ Make pale our cheek, chasing the royal blood \\ With fury from his native residence. \\ Now, by my seat's right royal majesty, \\ Wert thou not brother to great Edward's son, \\ This tongue that runs so roundly in thy head \\ Should run thy head from thy unreverent shoulders.
}

What is the actual domination of nature-the replacement of nature with culture?

It is the replacement of peasants and their lands as we can recall from early enclosures in the 1640s in Kett's rebellion. ${ }^{16}$ This effectively rounds out the plays and their subterranean personages; the servants Ariel and Caliban and the role of magic appropriated by Prospero is the pastoral fantasy in its own feudal world — an island — and an enclosure of its own. Richard's narcissisms find a moment of revealing just this in the speech of Gaunt:

A thousand flatterers sit within thy crown,

Whose compass is no bigger than thy head; 
And yet, incaged in so small a verge,

The waste is no whit lesser than thy land.

The metaphor of the verge and the land includes the people — peasants — that make this land other than waste. The vehicle of the figurative language condenses the affect of a people who would doubtlessly not forget rebellion against enclosure. We here this metaphor again a few sentences later:

Why, cousin, wert thou regent of the world,

It were a shame to let this land by lease;

But for thy world enjoying but this land,

Is it not more than shame to shame it so?

Landlord of England art thou now, not king

Here the suppression of this metaphoric meaning by aristocratic single-voicedness is obvious, only kings may rule the world and the land, and all that live on it are their inheritance.

\section{Autolycus}

Finally, we turn to the rogue Autolycus ${ }^{17}$ in The Winter's Tale; the ideologeme of the bandit as an instrument of providence does not merely conceal the outlaw that would be created in the religious wars and the fallout of the English civil war to come. The drama serves an imaginary of the past used to cover over what Giorgio Agamben has problematized in Homo Sacer; the life that anyone can take (Agamben 1998).

The margin of life here is the grotesque of the trickster, not that of the dying Gaunt, nor the rustic servants of Prospero. Autolycus declares his marginalization through theft and impersonation. He is also the model of a clever, industrious, and entrepreneurial 'spirit', what a later period will come to recognize in the colonizers, factors, and mercenaries, that are the first transnational forms of various India Companies that would change the world into a global economy.

Autolycus interests us as the concrete product of class fraction in a medieval figure and in a proto-modern anticipation of a new lawlessness, an anti-authority that is contemporary in populist libertarian imaginaries following the mythemes of the liberal Anglo-sphere in 'free-markets,' and liberal politics. ${ }^{18}$

However, most important in Agamben's assessment is the indeterminacy that a figure like Autolycus represents as cast out of society; his trickery is carefully mediated by Shakespeare as semi-magical and a remnant of paganism. Here again, magic is appropriated in the providential fortunes of the rogue during a time of rustic festivity. Nevertheless, this time the appropriation is the silent inevitability of the divine; no less uncanny than that deus ex machina in the sudden and strange pursuit and consumption by a bear.

In a passage echoing the trickery of Odysseus we are given the narcissism of Autolycus and a fellow Shakespearean grotesque:

\section{Clown}

What manner of fellow was he that robbed you?

AUTOLYCUS

A fellow, sir, that I have known to go about with

troll-my-dames; I knew him once a servant of the

prince: I cannot tell, good sir, for which of his

virtues it was, but he was certainly whipped out of the court.

Clown

His vices, you would say; there's no virtue whipped

out of the court: they cherish it to make it stay

there; and yet it will no more but abide.

AUTOLYCUS

Vices, I would say, sir. I know this man well: he

hath been since an ape-bearer; then a

process-server, a bailiff; then he compassed a

motion of the Prodigal Son, and married a tinker's

wife within a mile where my land and living lies;

and, having flown over many knavish professions, he 
settled only in rogue: some call him Autolycus.

But we cannot settle here, the cheat gives his genealogy: "My father named me Autolycus; who being, as I am, littered under Mercury, was likewise a snapper-up of unconsidered trifles." Bakhtin provides an understanding of the double-voiced character that is Autolycus as a satirizing character, and a destabilizing agent of the drama. This is a more complex subjectivity and a dangerous one. In this short analysis, other than Caliban, and the brief and insurrectionary tone of Gaunt in Richard II, Autolycus is uniquely positioned at the margin of society and is spoken in such a way to reveal the antagonism of class. This is sedimented in the appeal to aristocratic values throughout these plays, but Shakespeare undoubtedly in appealing to an audience of mixed loyalties, and in speaking to his contemporaries allows some of this to slip through in the clowning of Autolycus.

Shakespeare explores the life of the subject in Autolycus, who has the distinction of being the grandfather of Odysseus a figure that is as important to critical theory as to the metonymic sign of the artful wanderer in The Winters Tale. Adorno and Horkheimer explain the use of narcissisms like this:

\begin{abstract}
"The man who, for the sake of his own self, calls himself Nobody and manipulates resemblance to the natural state as a means of controlling nature, gives way to hubris. The artful Odysseus cannot do otherwise: as he flees, while still within the sphere controlled by the rock-hurling giant, he not only mocks Polyphemus but reveals to him his true name and origin, as if the primeval world still had such power over Odysseus, who always escaped only by the skin of his teeth, that he would fear to become Nobody again if he did not reestablish his own identity by means of the magical word which rational identity had just superseded. His friends try to restrain him from the folly of proclaiming his cleverness but do not succeed, and he narrowly escapes the hurled rocks, while the mention of his name probably brings down on him the hatred of Poseidon-who is hardly presented as omniscient. The cunning by which the clever man assumes the form of stupidity reverts to stupidity as soon as he discards that form. That is the dialectic of eloquence." (Horkheimer and Adorno 2002: 53)
\end{abstract}

The figure of Autolycus, the predecessor of Horkheimer and Adorno's mythological Odysseus, is for Shakespeare the mythological trickster. His appeal in The Winters Tale is a combination of aristocratic learning-the classical reference to Autolycus - and the profanation typical of carnivalesque. Unlike the other ideologemes of author and authority, this one, the low and satirical poetry of a rogue and a cheat is raised into relief through comic crimes. These crimes, spelled out in the case of Horkheimer and Adorno's Odysseus is eloquence, the performative speech that allows the estranged sign to overtake nature through culture. Autolycus is strangely saved the tragedy of Shakespearean characters such as Richard through his own satirical reflexions as his narcissisms are mimetic of a nature that is authentic in its naturalness because divine.

\title{
Myth
}

We are still living with this mythologeme: the outlaw, the wolf that is denied the city, denied becoming a zoon politikon has been inverted in the modern era as the entrepreneur, the privateer, the autonomous and self-sovereign sea-steader, the plutocrat that simply buys political power. Providence has since been revealed for what it has always been, the myth that allows power relations as the sole determinate of social relations.

This last inversion reveals the social relations of Prospero to have been the allegory of aristocratic valuation of good and bad servants (Ariel and Miranda are the good servants, Caliban and Prospero's scheming adversaries are the bad servants), and that allegory of Bolingbroke: banned from courtly (political) life only to return as the good king, banned by his own law, and pilgrim under divine law to recover the court (politics.). Autolycus the inventor of schemes is a useful key to Shakespeare's own re-establishment and re-stabilization of his dramas as performances imitative of a human shape always already cast on English discourse, despite surviving parody and satire. The entrepreneur of writing can be met with Horkheimer and Adorno's quote that cunning reverts to a stupefaction under the 'natural' and the familiar. Shakespeare's text is its own dangerous material that might well have earned the wrath of aristocratic authorities, but it had to be flattering enough to make this troupe its living. 


\section{Endnotes}

1. Socio-poetics is specifically the project of The Formal Method in Literary Scholarship A Critical Introduction to Sociological Poetics written with Pavel Nikolaevich Medvedev. Dialogism is developed and refined later in Problems of Dostoevky's Poetics. Bakhtin provides two conditions for a mature literary dialogism, which he attributes exclusively to Dostoevsky's sociopoietic (historical) accomplishment, first: "All of Dostoevsky's major characters, as people of an idea, are absolutely unselfish, insofar as the idea has really taken control of the deepest core of their personality....what is important is not the ordinary qualifications of a person's character or actions, but rather the index of a person's devotion to an idea in the deepest recesses of his personality." (Bakhtin 1984: 87) second: "The idea lives not in one person's isolated individual consciousness-if it remains there only, it degenerates and dies. The idea begins to live, that is. To take shape, to develop, to find and renew its verbal expression, to give birth to new ideas, only when it enters into genuine dialogic relationships with other ideas, with the ideas of others." (Bakhtin 1984: 87-88)

2. To make the point apparent in conventional Marxian terms, the givenness or naturalness of things, especially what is dependent and relational about the social, is a reification. Following Adorno, this problem of reification is linked to his complex understanding of mimesis. Importantly this device of demystification first develops in literary critique by Georg Lukacs.

3. This process is elaborated in The Political Unconscious as three analyzable moments in the process of interpretation: first as a "symbolic act," second as the "ideologeme," and third as the "ideology of form." (Jameson 1981:61-62). All of which are elements of his "metacommentary": "according to which our object of study is less the text itself than the interpretations through which we attempt to confront and to appropriate it." (Jameson 1981:x). For this study I am almost exclusively focused on the ideologeme: "the smallest intelligible unit of the essentially antagonistic collective discourses of social classes." (Jameson 1981:61). Importantly, Jameson's dialectical approach is comparative of 'methods' of interpretation, where the: "...juxtaposition with a dialectical or totalizing, properly Marxist ideal of understanding will be used to demonstrate the structural limitations of the other interpretive codes, and in particular to show the "local" ways in which they construct their objects of study and the "strategies of containment" whereby they are able to project the illusion that their readings are somehow complete and self-sufficient." (Jameson 1981:x). A limitation of this study is that I will not proceed beyond the analysis of the ideologeme to carry out this further task of considering the differing 'methods' of Bakhtin/ Medvedev from later writings of Bakhtin, or the differences between Pierre Bourdieu and Theodore W. Adorno on a short-circuit of socioanalysis by mediation, or Jameson and Kristeva on their respective use of the Bakhtinian ideologeme.
4. The plays are mimetic of pre-given tales. What is at work here is how these pre-figured stories were forgotten for novelty; a sense conspicuously overdeveloped in modernity as an uncritical appraisal of newness. This is a point of departure for Adorno and Horkheimer where they recognize the necessity of unpacking myth, including the forgetting of myth.

5. Bakhtin distinguishes two types of single-voiced discourse: as object-directed discourses and as discourse directed towards an others discourse. (Bakhtin 1984:185-189)

6. Another way to say this is that the use of metaphor in its radical, literary or dramatic performance is to flaunt incoherence as a way to remind the reader to use a connotative sense and not to take what is written or said literally or denotatively. In immanent critique the use of metaphor cannot be overlooked where it draws upon a genealogy of discourses through word choice, stylization, and especially parody. All of which are creative forms of mimesis, and especially important in signaling the reader or hearer to abandon the literal for a figurative context; to allow for un-familiar semblances to find form in our reception through hearing or reading. Sociopoetics in this sense is really a socio-poiesis inviting us into dialogue and the making of meaning dialogically, in dialogue with others.

7. Similar to Bourdieu's 'short-circuit effect,' Bakhtin cites this problem here: "Marxists often do not fully appreciate the concrete unity, variety, and importance of the ideological environment, and move too quickly and too directly from the separate ideological phenomenon to conditions of the socioeconomic environment." (Bakhtin and Medvedev 1978:15)

8. Kristeva follows Bakhtin here where the latter uses the terms 'extra-artistic' or 'extraliterary' to indicate ideological environments; encompassing utterances through assimilation, or as exteriorization in reference. These are modes of receptive sense, metaphoric or metonymic in their modes of interpretation. For the sociologist, these different receptive modes have some correspondence with moments of socialization in ideological environments, internalization and externalization respectively. In the former, a metaphorically receptive sense is necessary in representing incongruences of identity formation to oneself, what Bakhtin calls internal dialogism. The self is an overdetermined form that is more assembled than the cultural bric a brac used to form it, it is necessarily hubristic as Derrida has rightly observed, or as is explored here, narcissistic. In the latter, a metonymic receptivity is necessary for representing the environment, for a fetishization of things and reification of social beings through the metonym as the name-of-the-part-of-a-whole. That is, in reference to individuated voices at the cost of recognizing a dependence upon a social group discovered through the movement of history. This is of course a mode 
of obviation; anticipating and forestalling social consciousness.

9. Bakhtin: "An ultimate semantic authority requiring purely referential understanding is, of course, present in every literary work, but it is not always represented by direct authorial discourse." ... "Drama is almost always constructed out of represented, objectified discourses." (Bakhtin 1984: 188)

10. Multi-voicedness: "To introduce a parodic and polemical element into the narration is to make it more multi-voiced, more interruption-prone, no longer gravitating toward itself or its referential object." (Bakhtin 1984: 226). Kristeva discusses several early forms of multi-voicedness or polyphony as they form in philosophical traditions of Plato and Aristotle: "[the dialogues of Plato and Xenophon] Not as much rhetorical as popular and carnivalesque, it was originally a kind of memoir (the recollections of Socrates's discussions with his students) that broke away from the constraints of history, retaining only the Socratic process of dialogically revealing truth, as well as the structure of a recorded dialogue framed by narrative." (Kristeva 1980: 81). She also follows Bakhtin in her comments on Menippean Discourse: "In other words, the dialogism of Menippean and carnivalesque discourses, translating a logic of relations and analogy rather than of substance and inference, stands against Aristotelian logic. ... Indeed, Menippean discourse develops in times of opposition against Aristotelianism, and writers of polyphonic novels seem to disapprove of the very structures of official thought founded on formal logic." (Kristeva 1980: 85).

11. (1527-1608) Court Astrologer and advisor to Queen Elizabeth I.

12. e.g. Francis Bacon (1561-1626), Shakespeare's contemporary (1564-1616).

13. Terry Eagleton here: "At this point, therefore The Tempest conveniently folds itself up by inviting the audience to applaud, thus breaking the magic spell by foregrounding the theatrical fictionality of its own devices." (Eagleton 1986: 96).

14. Bakhtin describes double-voicedness: "Discourse with an orientation toward someone else's discourse" and as having many types including: "Unidirectional double-voiced discourse," "Vari-directional doublevoiced discourse," and an "active type (reflected discourse of another)”. (Bakhtin 1984:199).

15. Very seriously. Bakhtin observes internal dialogism as a double-voicedness in a spectrum of possibilities: "At its outer limit this tendency leads to a disintegration of double-voiced discourse into two discourses, into two fully isolated independent voices. The other tendency, which is inherent in unidirectional discourses provided there is a decrease in the objectification of the other's discourse, leads at its outer limit to a complete fusion of voices, and consequently to single-voiced discourse of the first type. Between these two limits fluctuate all manifestations of the third type." (Bakhtin 1984:198). Kristeva notes that: "Pathological states of the soul, such as madness, split-personalities, daydreams, dreams, and death, become part of the narrative (they affect the writing of Shakespeare and Calderon). According to Bakhtin, these elements have more structural than thematic significance; they destroy mans epic and tragic unity as well as his belief in identity and causality; they indicate that he has lost his totality and no longer coincides with himself." (Kristeva 1980:83).

16. This is prefigured in the metonymy of Shakespeare's Gaunt where he uses the reference of enclosure: "incaged in so small a verge" to Richard's narrow vision of England as it's pre-figured modernization under Richard as "landlord." The latter is a point shared in Terry Eagleton's critique, however, I am emphasizing the ideologeme, the rise of Bourgeois and mercantile evaluations of land over the traditional and feudal possession of land as part of divine right. But we should attend to another point here, and that is the peculiar appearance of time-space to a critical literary sense. Shakespeare's Richard II de-historicizes the past if we forego the historicality of Shakespeare's own language. But to depend upon historicization is also to depend upon time such that the "simultaneity of the nonsimultaneous" exist in contradiction where literary sense is honed by historical conditions. For us, the archaisms of Shakespeare invite precisely this sense; in 1640 the figure of speech would have enjoyed a very different sense in its figurative distance.

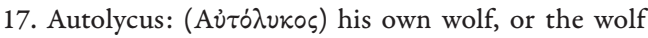
itself.

18. Here Kristeva's insight is particularly interesting, in that she recognizes Menippean discourse for its 'contrasts' including: "virtuous courtesans, generous bandits, wise men that are both free and enslaved," as well as 'misalliances' (Autolycus involves himself in several), and she notes: "Its language seems fascinated with the "double" (with its own activity as graphic trace, doubling an "outside"'. (Kristeva 1980:83). Her final comment: "The multi-stylism and multi-tonality of this discourse and the dialogical status of its word explains why it has been impossible for classicism, or any other authoritarian society, to express itself in a novel descended from Menippean discourse." (Kristeva 1980:83). This play, to recall for the reader, is no novel. And, following Bakhtin's dialogism, Shakespeare's work is only embryonic as multi-voiced. Nonetheless, Kristeva has managed to track Menippean dialogue as an intertextual event in Shakespeare's narrative (q.v.).

In another sense, a critical and literary sense of the sociopoiesis of drama and narrative, we encounter Autolycus as a returning figure that both confabulates and fetishizes anti-authority. In a dialogical analysis this ambivalent character has the important social distinction of being beyond the polis (he is named after a beast, in the manner of a godling) and on this sense, a-social. In this specific sense the horizon of the political is turned into a boundary; only fantasies can persist beyond the pale of Realpolitik. 


\section{References}

Agamben, Giorgio. 1998. Homo Sacer Sovereign Power and Bare Life. Stanford U. edited by W. Hamacher and D. E. Wellbery. Stanford: Stanford University Press.

Bakhtin, Mikhail. 1984. Problems of Dostoevky's Poetics. edited by C. Emerson. Minneapolis: University of Minnesota Press.

Bakhtin, Mikhail Mikhailovich and Pavel Nikolaevich Medvedev. 1978. The Formal Method in Literary Scholarship A Critical Introduction to Sociological Poetics. Baltimore: The John Hopkins University Press.

Bernstein, J. M. 2000. "Re-Enchanting Nature." Journal of the British Society for Phenomenology 31(3):277-99.

Bourdieu, Pierre. 1993. The Field of Cultural Production. Polity Pre. edited by R. Johnson. New York: Columbia University Press.

Eagleton, Terry. 1986. William Shakespeare. New York: Basil Blackwell, Inc.

Hansen, Miriam. 1992. "Mass Culture as Hieroglyphic Writing: Adorno , Derrida , Kracauer.” New German Critique Special Is $(56): 43-73$.

Horkheimer, Max and Theodor W. Adorno. 2002. Dialectic of Enlightenment Philosophical Fragments Cultural Memeory in the Present. edited by G. S. Noerr. Stanford: Stanford University Press.
Hylton, Jeremy "The Complete Works of William Shakespeare." http://shakespeare.mit.edu/index.html Accessed April 30, 2019.

Jameson, Frederic. 1981. The Political Unconscious Narrative as a Socially Symbolic Act. Ithaca: Cornell University Press.

Kristeva, Julia. 1980. Desire In Language A Semiotic Approach to Literature and Art. New York: Columbia University Press.

Ricouer, Paul. 1991. From Text to Action Essays in Hermeneutics, II. edited by J. M. Edie et al. Evanston: Northwestern University Press. 
